\title{
Aby Warburg's Wildest Dreams Come True?
}

\section{Hans Brandhorst}

Whether it is true that in the midst of the "digital revolution" we should be disappointed about its results in the field of art history is a question that is both premature and lacking in analytical acuity. But even if we take this rather vague concept of the "digital revolution" to simply mean that image researchers have an unprecedented flood of reproductions at their fingertips, we can still detect real feelings of unease about what this flood has brought us so far.

This article takes a simple visual motif — one person carrying another — as a possible starting point for iconographic research. In imagining how source material could be collected, arranged and re-arranged, it refers in a general way to the screens with photographs that Aby Warburg used to set up to help him develop ideas in the process of his research.

If we were able to create corpora of sources made accessible in such a way that continuously rearranging them by visual motif and meaning were easy, and if we could seduce researchers and catalogers to cooperate in enriching them, the study of iconography could make a significant leap forward.

Keywords: Mnemosyne, Bildatlas, Warburg, iconography, emblems, Iconclass, Arkyves, helpfulness, friendship

Never before have so many researchers in the humanities had such easy access to so many historical sources - both textual and visual. Never before have so many humanities scholars had such easy access to so many channels to publish the results of their investigations. Never before has the call for well-structured information about our visual heritage been so loud. And never before have so many software engineers and information specialists been so keen to collaborate with colleagues in the humanities ${ }^{1}$.

These statements are intuitive, perhaps even slightly naive assumptions rather than conclusions based on the investigation of large amounts of data. Still, they seem convincing enough to make us wonder about the paradoxical situation that in the midst of the digital revolution there is a fairly widespread feeling of unease about its results in the field of art history. Of course, the "digital revolution" is a concept that by now is more diluted than the average homeopathic drug, but even if we reduce its scope, and take it simply to mean that we are witnessing the explosive increase of easily available reproductions of visual sources, we are not very surprised that a recent issue of Visual Resources bore the title "The Crisis in Art History."

To actually check the validity of these assumptions and the reality of this pessimism, we would need — on the one hand - a survey of the fast-growing world of online catalogs and 
databases of museums, archives, libraries and other heritage organizations, and - on the other hand - an overview of (art-) historical curricula and publications. It would be a Herculean task to gather that amount of data - and even then it might simply be too soon to deal with this issue at an adequate analytical level.

Since new research questions arise in interaction with existing ones, I think it will be a more fruitful approach to test my assumptions against the background of an ongoing research project. I propose to find out, at a very concrete level, whether we indeed have easy — and efficient — access to a wealth of digital resources; whether we can indeed publish about our research in a really new way; and whether we really have the new tools at our disposal to take our research to a higher level, wherever that may be.

Along the way, we shall inevitably come across issues like enriched datasets, persistent identifiers and persistent URLs, collaborative indexing and collaborative publishing, copyright issues, standardization, Iconclass and other controlled vocabularies and thesauri, and the quality and the organization of raw data.

However, IT and vocabulary issues should not be the main stops along our road. They should be no more than service stations we make use of while our main destinations remain historiographical questions.

As my point of departure I shall take some iconographical questions, so searching for themes and motifs across paintings, prints and drawings will an obvious first step. Singled out for this article, my questions are actually part of a wider investigation into the role of the famous Dutch humanist Desiderius Erasmus' (ca. 1467-1536) huge collection of classical proverbs, the Adagiorum chiliades (first published in 1500), as a source of imagery and iconography. Therefore other sources, textual ones such as proverbs, and bi-medial ones such as emblems, both circulating widely in early modern Europe, will be important as well. I shall report on my adventures in gathering material, since such a search should shed light on how digitized visual and textual sources are presented and made accessible, in particular by subject matter.

An important aspect of the methodology of this wider investigation is to follow the associative links that connect visual and textual images, motifs and themes. Particularly in the area of emblem studies, significant research effort has been invested in reconstructing these associative chains between artefacts. There is, moreover, abundant circumstantial evidence that building these chains formed an important aspect of what we now often call the emblematic game. The parallel between the early modern "web of images" and the hyperlinked Internet has been noted by more than one observer.

One ambition of my research project is to organize the gathering of that evidence in a more systematic way. It is tempting to compare this procedure with the way Aby Warburg supported his highly original research, pinning the images that he was using to develop his ideas on large screens. Needless to say we would be turning things upside down if we thought that "pinning" digital images on digital screens would by itself lead to interesting research questions, let alone to anything as innovative as the work of Warburg. 
Yet it is a seductive idea to imagine that if Aby Warburg were to have access to the digital laboratory we have at our disposal today, he would feel that his wildest dreams had come true. ${ }^{2}$

\section{From Documentation to Discovery Tool: (re-)Constructing Chains of Associations with the Help of Visual Resources}

The motif that I want to investigate is that of "a person carrying someone on the back or the shoulders."

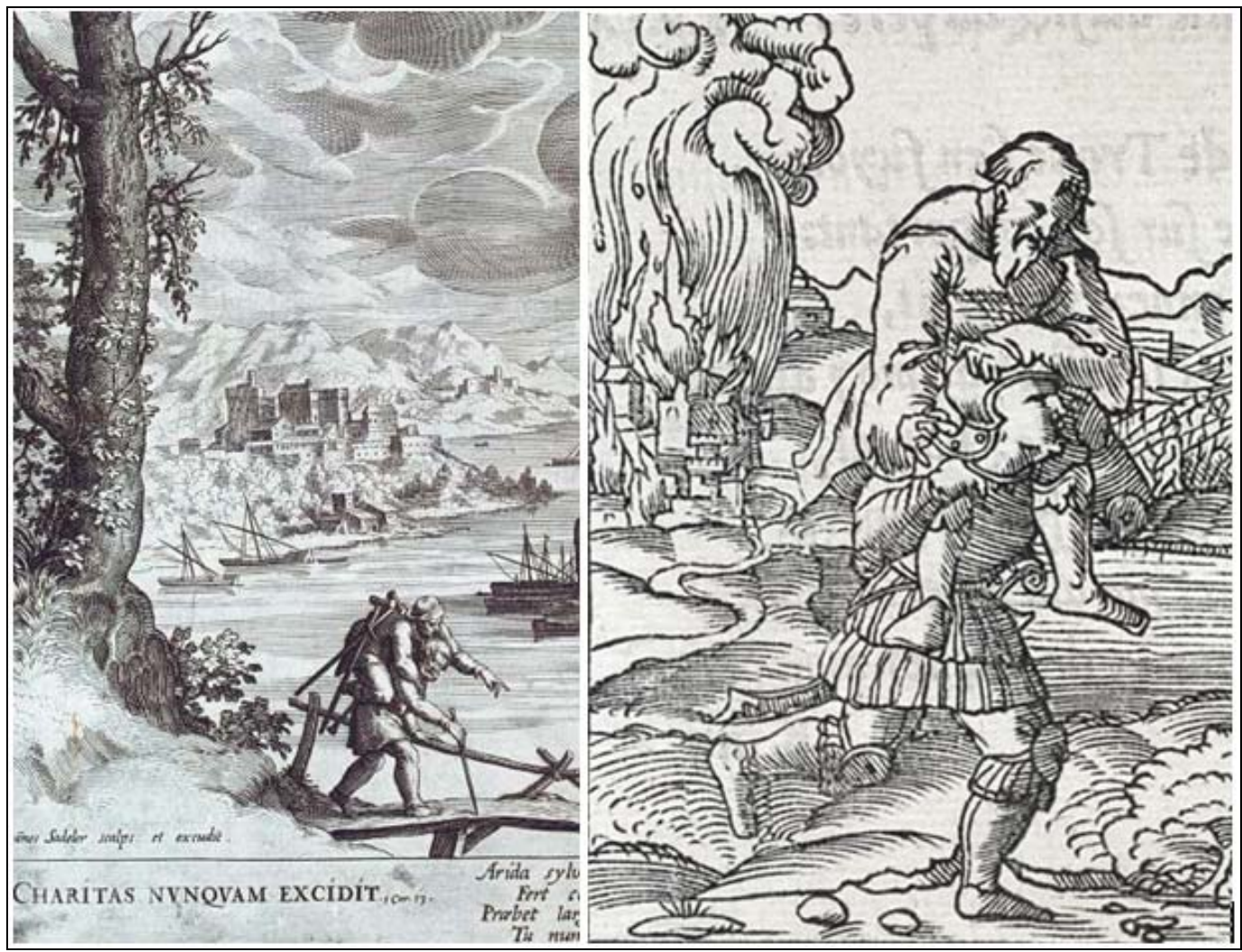

Figure 1. Two examples of "a person carrying someone." Both are details taken directly from online resources. On the left is a detail from an engraving by Jan (I) Sadeler (Herzog August Bibliothek, Wolfenbüttel, shelfmark a1-2372). Direct access to the digital copy is available through a so-called Persistent Uniform Resource Locator (PURL). In this case: http://diglib.hab.de/?grafik=graph-a1$2372 .^{3}$

On the right is a detail from a digital copy of Andrea Alciato, Les Emblemes, Paris, Chrestien Wechel, 1542, p. 150. http://www.emblems.arts.gla.ac.uk/alciato/emblem.php?id=A42a069 is its URL, a relatively stable address, but not officially a PURL. The detail is part of the pictura of emblem LXIX which has Pietas filiorum in parentes (Honour from children towards parents) as its motto.

Figure 1 shows two of the more familiar themes that use the motif: the halt leading the blind (a blind man carrying a crippled man) and Aeneas carrying Anchises from burning Troy (Aeneas 
rescuing his father by carrying him out of the city). Among the Adages we find "Humeris sustinere" (To carry on one's shoulders - Adagium IV v 93), and "In cotyla gestaris" (You are carried piggyback - Adagium II x 72).

It is tempting now to dive headlong into the problems of subject description, controlled vocabularies, and systematic classification. It will be glaringly obvious to anyone who has ever done a search on line that there can be a world of difference between query results, dependent on how we formulate a question. "The flight from Troy" and "Aeneas Rescuing Anchises" are just two phrases that refer to the same theme but do not share a single word. ${ }^{4}$ Both produce results in Web search engines such as Google, and if the search engine queries a database that is big enough, the results for both variants can be quite numerous. The same holds for "the halt leading the blind," a motif that can also be described in many different ways. Those descriptions, moreover, will use more general words like "a blind man carrying a cripple," "a lame man on the back of a blind man," and "a blind man with a paralytic on his back," which will produce results from a broader range of material than a specific literary theme like that of "pius Aeneas."

Add to the mix that a) queries like "a person carrying someone on his back" or "carrying a person on one's shoulders" are even less specific and therefore much more problematic than those using iconographic jargon, that b) quite a number of potentially relevant databases use their native Italian, French, German or Dutch for their descriptive metadata, and that c) the depth of indexing in online museum and library catalogs varies wildly, and the feeling that the digital revolution has so far produced mixed results in the field of art history becomes understandable.

Obviously, this is a problem that has been recognized at about the same time that the first computerized catalogs were created, and a significant amount of effort has been spent on standardization in the past twenty-five years or so.

However, the question is not whether we will be able to offer information about visual sources in a more standardized, consistent and systematic way, making ourselves less dependent on, for example, language differences. Of course we can. The real question is whether in documenting our sources we shall ever be able to systematically be one step ahead of researchers, providing them with ready-made answers when they are asking new questions. I am afraid that the answer is "no." 


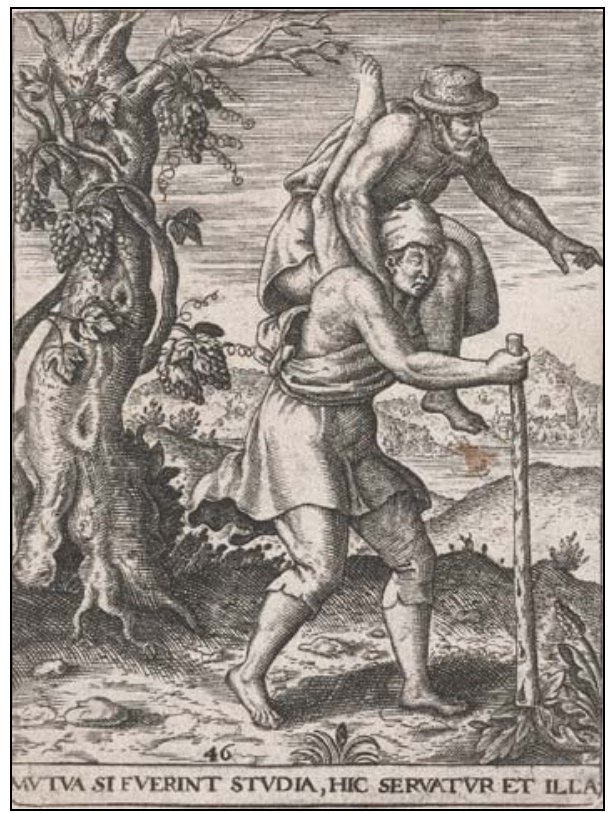

Figure 2. The Halt Leading the Blind. Pictura for emblem 66 - "Der Blindt vnd der Lahm" in Joannes de Bry, Proscenium vitae humanae, Frankfurt, Wilhelm Fitzer, 1627. (Herzog August Bibliothek in Wolfenbüttel, xb-6550). PURL: http://diglib.hab.de/drucke/xb-

$6550 /$ start.htm?image $=00158$. The text clarifies that if the two men share a mutual goal, this solution serves them both.

Looking into why the answer is a negative one, figure 2 is a good place to start. At first sight it is just another example of "the halt leading the blind." But if we look a little further, we realize that De Bry (1561-1623) actually combined two emblems from Alciatus' Emblematum libellus. ${ }^{5}$ (Figure 3)

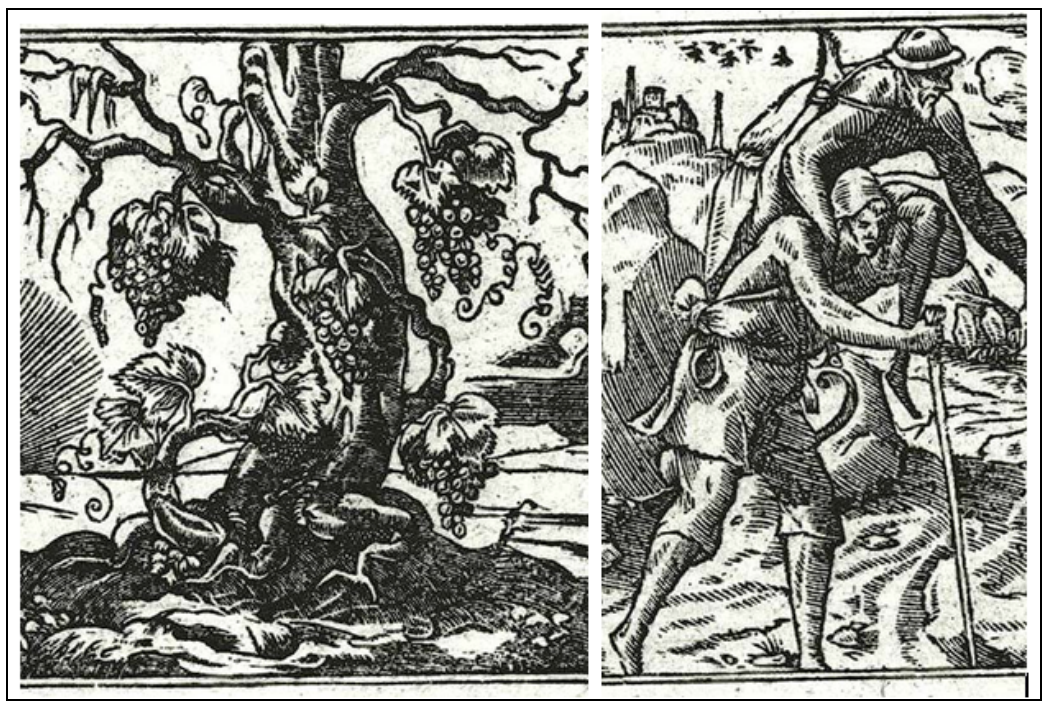

Figure 3. On the left is the pictura of the emblem Amicitia etiam post mortem durans (Friendship surviving death) and on the right that of the emblem Mutuum auxilium (Mutual help). They are 
emblems 159 and 160 in the edition that was produced in 1551 by Macé Bonhomme for Guillaume Rouille.

The elm tree continues to support the vine after its own death, the blind man supports the cripple who tells him where to go, so helpfulness is an obvious shared theme between these emblems. A further element of importance is the reciprocity of the assistance that the blind and the lame man offer each other.

Looking again at the Sadeler print in Figure 1, we now see the tree on the left in a different light, certainly if we take the text on the print into account, which juxtaposes the withered tree, covered by green ivy, with the blind man carrying the lame man who shows him the way. The corresponding motto Love never fails (1 Corinthians 13:8) is echoed on the right side of the print by He that has, should give to him that has not (Luke 3:11), illustrated here by a horseman giving alms to a beggar. ${ }^{6}$ (Figure 4 )

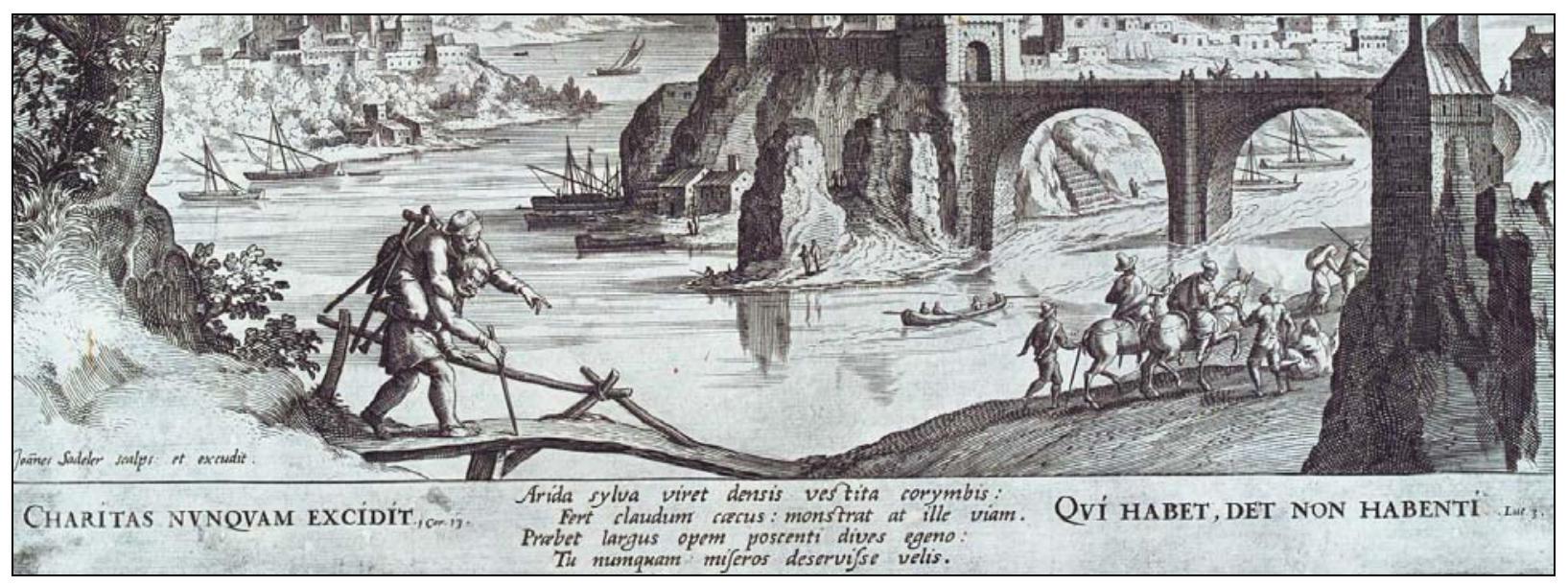

Figure 4. Charitas nunquam excidit — Qui habet det non habenti.

So, starting with a simple visual motif - carrying a person on the back or shoulders — it took very little effort to identify themes and motifs potentially relevant for further searches. Let me list them. First some "iconographies" of varying degrees of specificity:

- carrying someone on the back or shoulders

- an (elm) tree supporting a vine (or ivy)

- a blind man carrying a lame man

- a son rescuing/carrying a parent — Aeneas carrying Anchises,

- a rich man giving alms to the poor

On another level of abstraction and often helped by the texts to which the imagery is linked, I have identified a few broader themes: 
- (mutual) helpfulness

- friendship

- immortality

- cooperation

- charity - caritas - love

- filial love

- generosity

- blindness

- paralysis — deformity [mutuum auxilium]

[amicitia ... durans]

[...post mortem durans]

[mutuum auxilium]

[charitas nunquam excidit]

[pietas filiorum in parentes]

[qui habet, det non habenti]

Even though they are suggested by only a handful of documents, these iconographies and themes point to various directions for research. For example: the way concepts like friendship, helpfulness or mutual cooperation are visualized, and the way that they are embedded in webs of references and associations could help us understand how they were perceived in early modern Europe. Or an investigation into the "iconography of poverty" could start with a query for documents that combine the act of giving alms with representations of people suffering from deformities and handicaps. It would not be difficult to come up with more examples, but let us continue to follow the trail of the halt and the blind. My next stop is the theme of Concordia, to which these themes are linked in the emblem by Gabriel Rollenhagen (1583-1619?) of which a detail is shown in Figure 5: the blind man with the lame man on his back, about to cross a narrow plank that spans a river. ${ }^{7}$

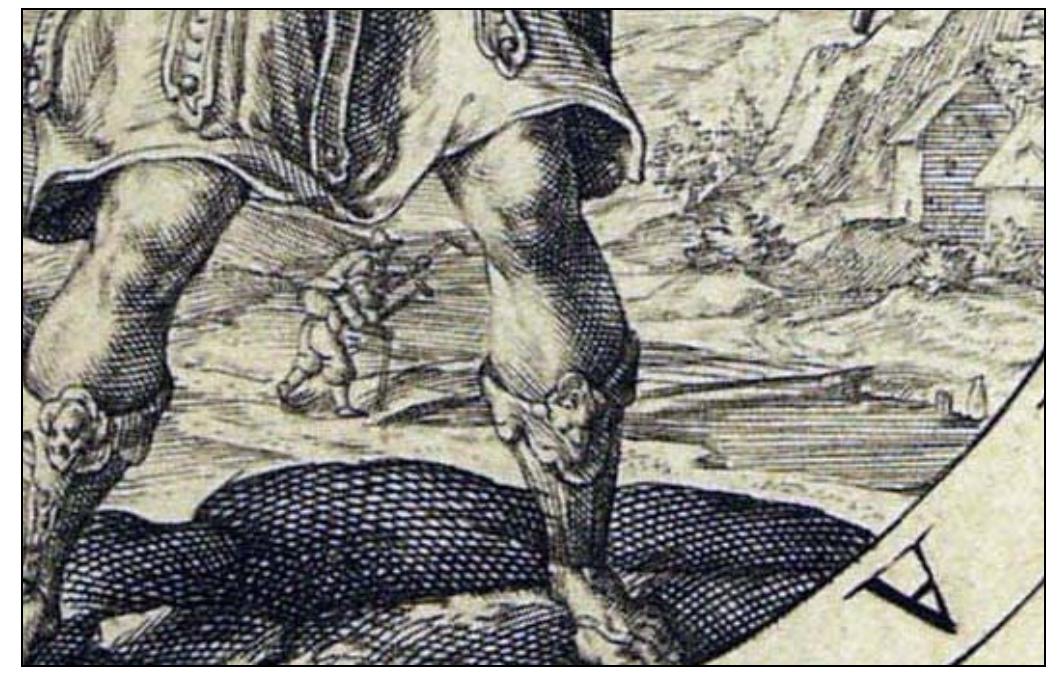

Figure 5. Gabriel Rollenhagen, [Nucleus emblematicus] centurio 2, Utrecht 1613, a detail of the pictura of emblem 45, Concordia insuperabilis (Invincible unity).

The scene is tucked away in the background of a representation of king Geryon (Figure 6), who is here depicted having six arms, holding a weapon in each of his six hands. The motto Concordia 
insuperabilis (Invincible Unity) and the fully armed king, though obviously related to the concept of cooperation, undeniably adds a militaristic dimension to the theme of the halt and the blind.

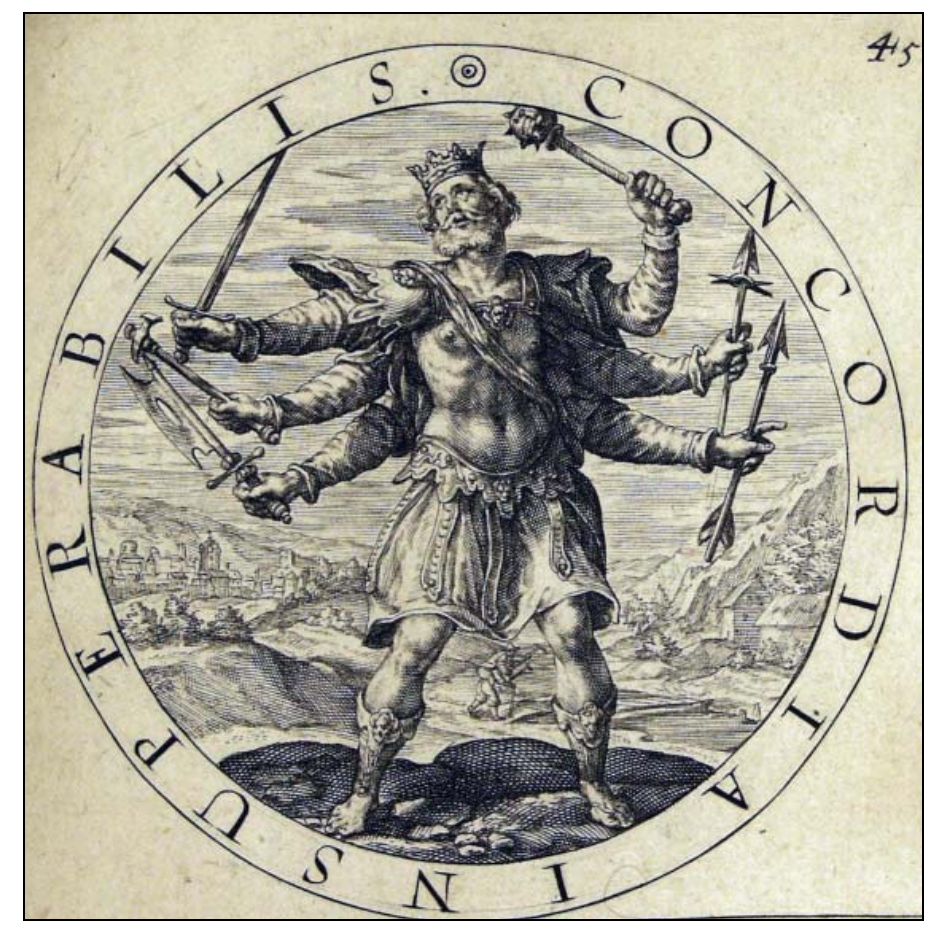

Figure 6. Gabriel Rollenhagen, [Nucleus emblematicus] centurio 2, emblem 45.

A very different facet is added by Geoffrey Whitney (ca. 1548-ca. 1601) who re-uses Alciato's Mutuum auxilium emblem in his Choice of Emblemes. Whitney's social commentary states that the poor and rich belong together by divine decree: the rich provide guidance (eies), the poor their labour (legges):

So without poore, the ritche are like the lame:

And without ritche, the poore are like the blynde:

Let ritche lend eies, the poore his legges wil frame,

Thus shoulde yt bee. For so the Lorde assign'd,

But there is more: in a marginal Latin gloss, which could be summarized as "helpfulness is next to godliness," Whitney quotes the adage "Homo homini deus" (Man is a god to man - Adagium I i 69). The ancients, so Erasmus explains in his commentary about this proverb, saw helpfulness as a basic characteristic of the gods, and if one man helps another, he behaves like a god. In an emblem that uses the same adage as its motto, the French humanist Pierre Coustau says that the refusal to help a friend goes against both nature and the Gospels:

... Car se monstrer negligent aux affaires des amys quand ilz ont besoin, est autant con tre nature que contre la doctrine de l'Evangille... 
What makes this all the more interesting in our present context, is that for the story that Coustau uses to make his point, carrying a burden is pivotal: an ox asked his friend the camel to take some of the weight from his back. The camel, however, refused to help him. When the ox could bear his burden no longer, the camel was ordered to carry not only the ox's burden but also the ox himself (Figure 7). Here carrying is turned form a voluntary act of helpfulness into a punishment.

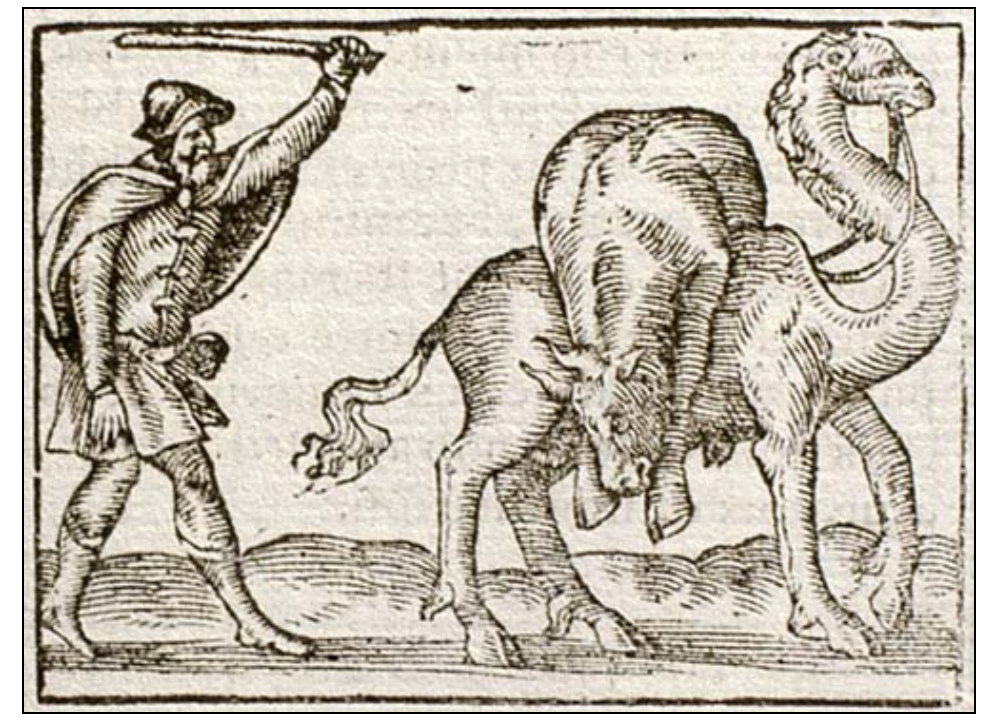

Figure 7. Pierre Coustau, Pegma, (Lyon, Macé Bonhomme, 1555). Taken from the digital copy on the Web site French emblems at Glasgow. For more information about this emblem go to its direct URL: http://www.emblems.arts.gla.ac.uk/french/emblem.php?id=FCPa094.

Geoffrey Whitney is not the only one to link the act of carrying someone to the concepts of wealth and poverty. Interesting examples from the seventeenth century are found on line, on the Web site of the Amsterdam Rijksmuseum. Adding yet another layer to the motif's potential, Adriaen van de Venne (Figure 8) draws a man carrying Vrouw Weelde (Lady Wealth) to illustrate the message that strong legs are needed to carry wealth. This may be taken as an exhortation to act sensibly and with moderation, even though the means are there to live extravagantly. It may also be seen as a warning to young (and maybe not so young) men to avoid "high maintenance" females. 


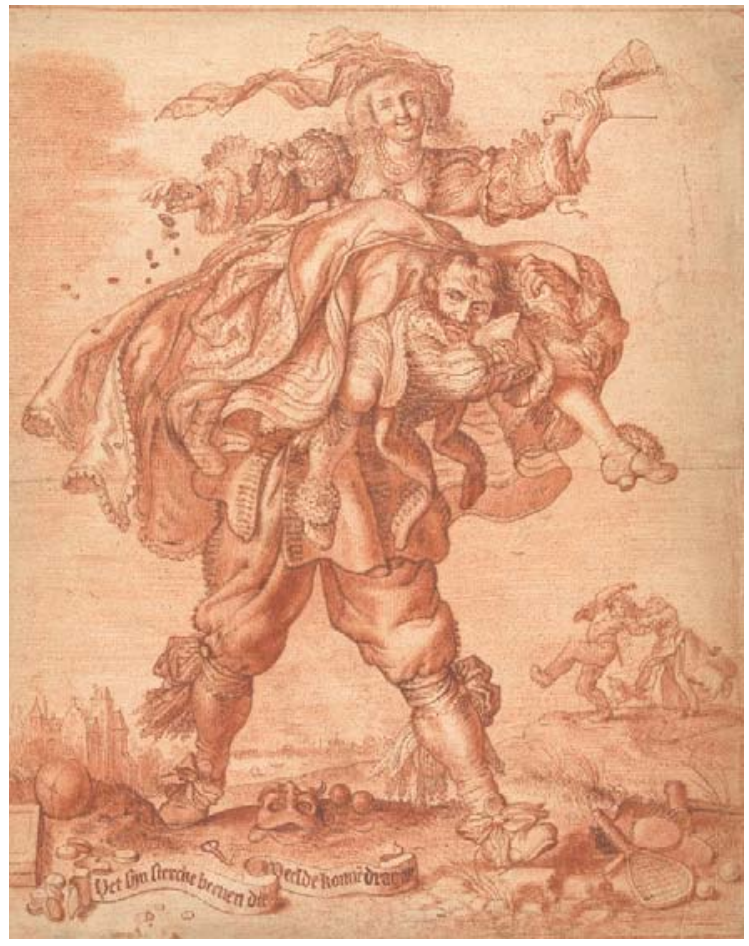

Figure 8. Drawing by Adriaen Pietersz. van de Venne (ca. 1589-1662): a man carrying a young woman (Lady Wealth) who is holding a pipe and a glass with one hand and strewing money with the other. The drawing is inscribed Het sijn stercke beenen die Weelde konnen dragen (Strong legs are needed to carry Wealth). It is found (with an explanation in Dutch) at: http://www.rijksmuseum.nl/collectie/RP-T-00-758/.

Using Van de Venne's imagery to illustrate a moral message is something that could be entrusted to the Dutch politician and poet Jacob Cats (1577-1660). An adaptation of the drawing is used as the pictura for emblem 56 in his Spiegel van den Ouden ende Nieuwen Tijdt (The Hague, 1632). A slightly different way to get a comparable message across is chosen for an engraving after a design by Karel van Mander (1548-1606), ascribed to the workshop of Hendrick Goltzius (15581617) (Figure 9). It shows a man carrying Poverty - a woman with thin legs, tousled hair, and ragged clothes - on his back. The couple pass by a rotund, well-dressed woman lying on her back - Wealth. The message is an obvious double one. It is easier - literally - to carry a light woman than a heavy one. It is also easier - metaphorically — to bear poverty than wealth. 


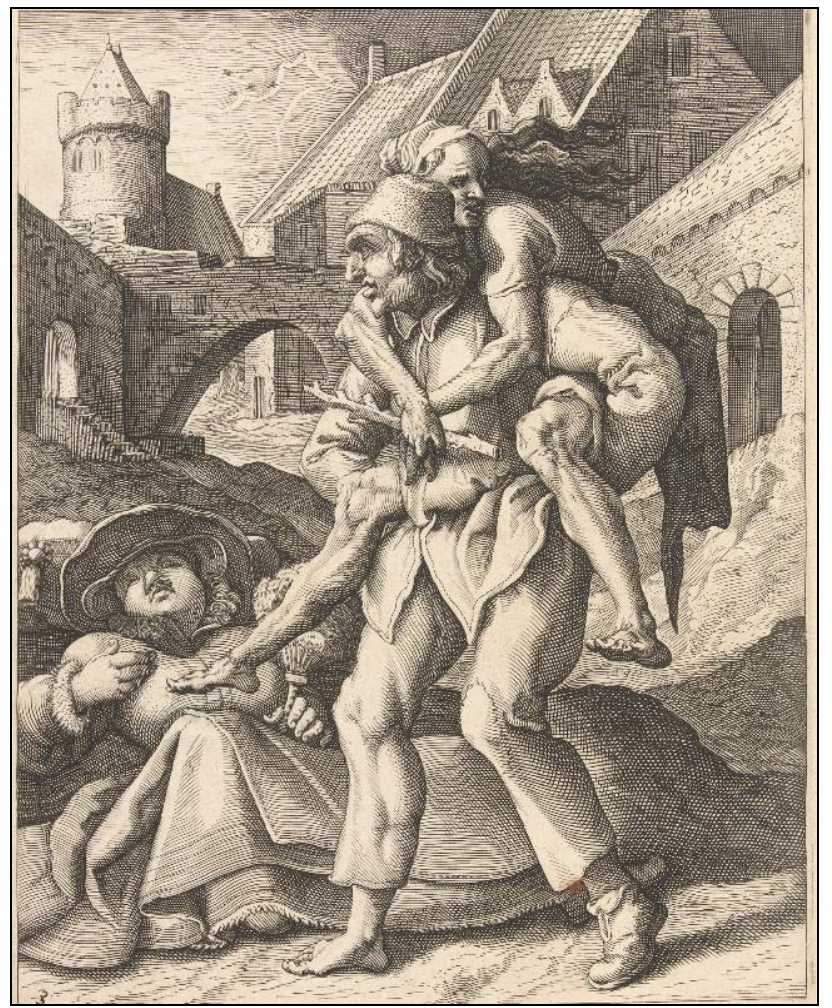

Figure 9. Hendrick Goltzius and Karel van Mander, Armoede draag je makkelijker dan Rijkdom. (It is easier to carry Poverty than Wealth). http://www.rijksmuseum.nl/collectie/RP-P-BI-4303/.

In the same book where we find the man carrying Lady Wealth - Jacob Cats's Spiegel van den Ouden ende Nieuwen Tijdt - we also find an emblem with a picture of an elderly man carrying a Fool on his shoulders (Figure 10). Playing on the text of Proverbs 11:29 ${ }^{8}$ (The fool shall be servant to the wise of heart), Cats maintains that a truly wise man possesses enough wisdom to suffer fools, and the truly strong/wise will compensate for their fellow man's weaknesses/folly. It is likely that at least some of the associations mentioned above would have occurred to Cats' contemporaries upon seeing this image. 


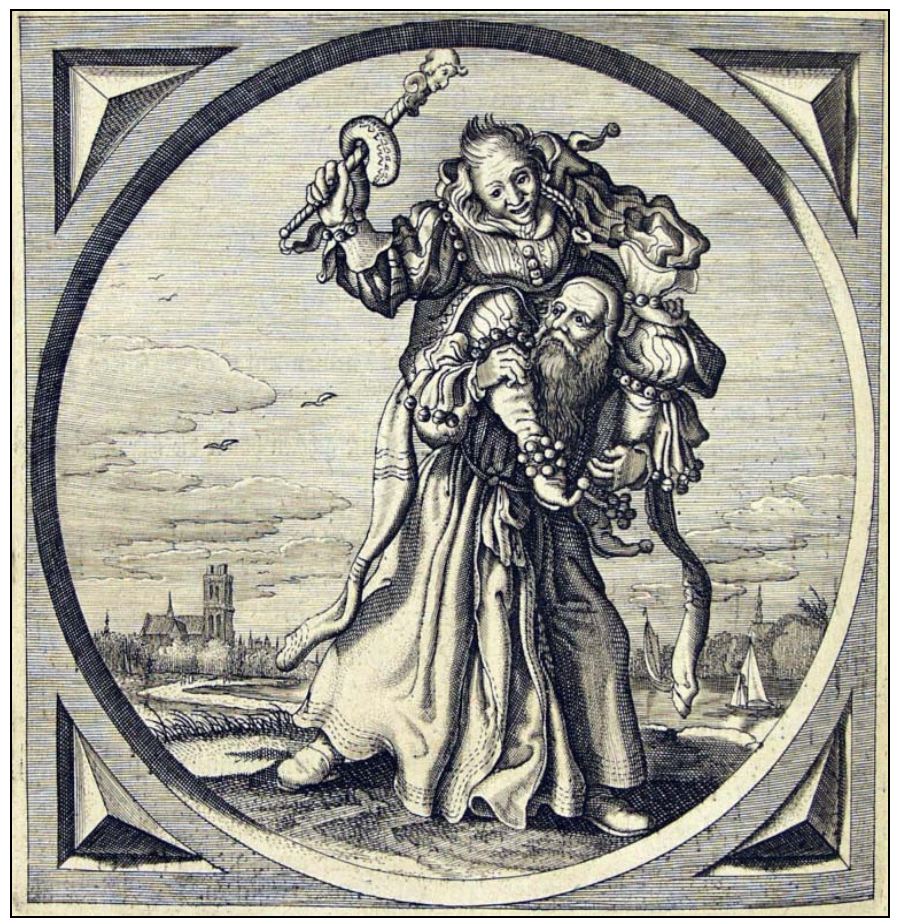

Figure 10. Jacob Cats, emblem from his Spiegel van den Ouden ende Nieuwen Tijdt.

Were we to focus on the theme of mutual cooperation, quite a few new motifs could be added to our stock. For now I will limit myself to adding just two more links to the chain before evaluating where this associative linking has taken us (Figure 11). First of all, the theme is expressed by Gabriel Rollenhagen (active 1613) in the motto Manus manum lavat (One hand washes the other) and a picture of Cupid pouring water on the right hands of a husband and wife. ${ }^{9}$ And finally, something completely different: Peter Isselburg (ca. 1580-after 1630) illustrates this theme with one goat kneeling on a narrow bridge to allow a fellow goat to step over his back, the motto stating that it is helpful to give way. 


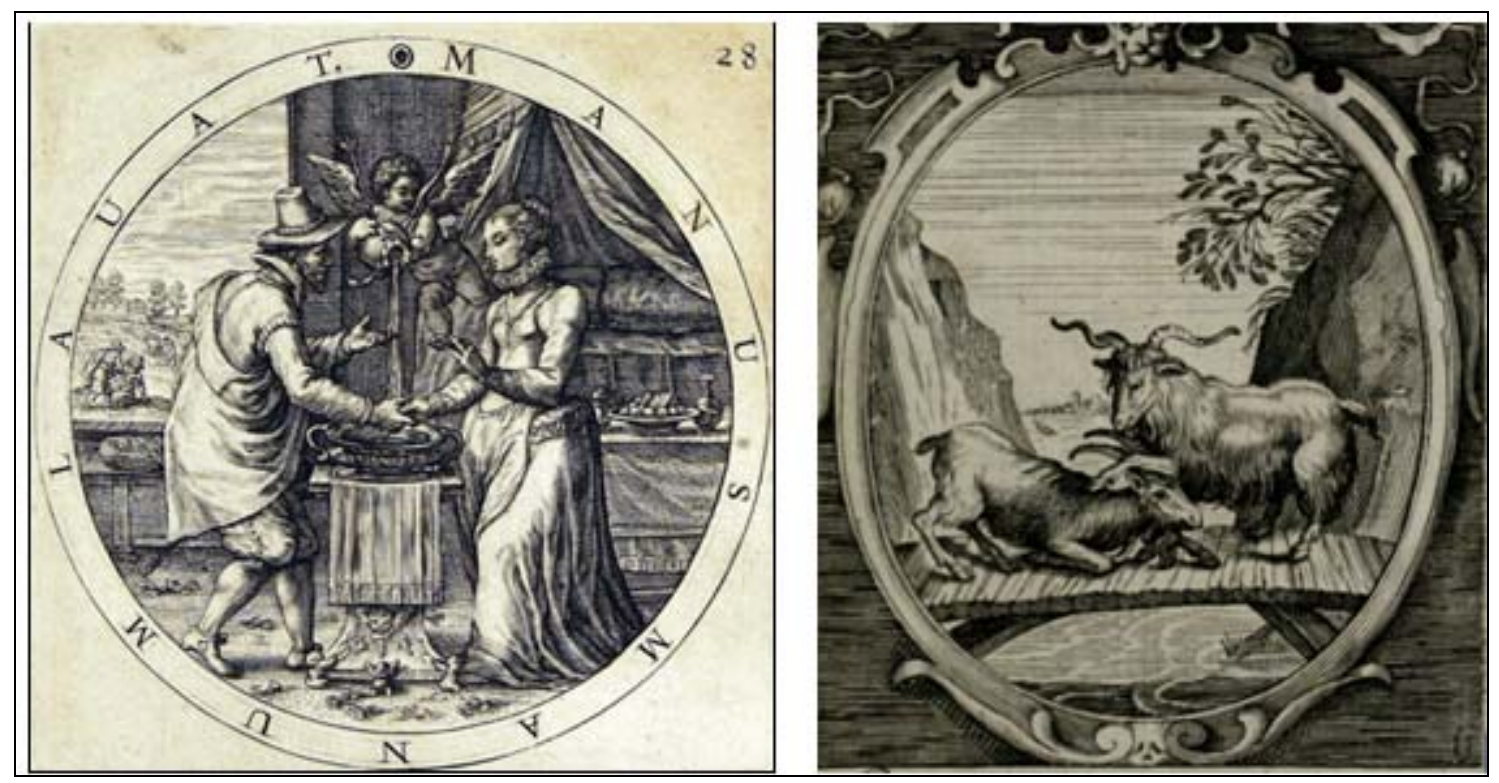

Figure 11. Details from George Wither, A Collection of Emblemes (Printed by A.M. for Robert Allot, 1635), emblem 128 (left), and Peter Isselburg and Georg Remus, Emblemata Politica, (Nuremberg, 1617) (right).

\section{Web Catalogs and Discovery Tools}

The evidence for the associations and links I have discussed above is either provided by the emblem authors and print designers themselves, because they are explicit about their sources, or is circumstantial and rests on probabilities. Since the purpose of this article is not primarily historiographic, there is no real need for more detail to make my final point. So, let us return to the original issue: Why do we have this slightly vague apprehension about the efforts that have been invested to date in the digitization of our visual heritage? I believe that the answer is that our feeling of disappointment means that there is some kind of mismatch between expectations and results, and that we should reflect on our expectations. In the context of this article, this is limited to researchers' expectations about iconographical information.

Earlier I denied that in documenting our sources we would ever be able to systematically be one step ahead of researchers, providing them with ready-made answers when they are asking new questions. My reason for answering this question in the negative is partly theoretical and partly practical.

We do not have to dig deep in the philosophy of science to come up with the idea that historical research only merits that name if it aims for insights that go at least one step beyond the combined wisdom of a digital resource's metadata. In other words: the whole point of historical research is to process sources, enrich them with ideas, approach them with hypotheses, and organize them in such a way that new light is shed on them.

As a consequence we need to accept - trivial as this may sound - that cataloging should not aim to replace research but merely to enable it. Even if museums and libraries employ specialists and use one or more controlled vocabularies to record iconographical information about their 
sources, the whole purpose of making them available should be to offer researchers an opportunity to enrich them with their own ideas.

My examples are selected from Arkyves, ${ }^{10}$ a Web catalog that does precisely that: it offers iconographic information created by specialists with the help of Iconclass, a controlled vocabulary for expressing iconographical themes. The Arkyves catalog is the result of a long-term effort to aggregate the content of databases that are scattered across the Web but all share the use of Iconclass for their subject indexing. Because Iconclass is a systematic classification, the semantics of its terms are unambiguous, which turns a query with very general words like carrying, person, and back into a query for a very specific motif. As Figure 12 shows, the Iconclass system also includes useful cross-references.

My reason for using Arkyves is not that it is the only database allowing for retrieval using Iconclass. A site like the German Bildindex — www.bildindex.de — also allows for Iconclass searches. It contains some 2 million documents, indexed according to very high standards. Nor did I choose this resource because I personally indexed thousands of the objects in it, and am fairly familiar with its content of approximately half a million images.

The reasons for my selection are twofold. Firstly, the images that I have included here are available on the open Web with no restrictions, which means that I can avoid the burdensome task of obtaining (and paying for) permission to use them. ${ }^{11}$ Secondly, and more importantly, we are at present developing the instruments that will transform the Arkyves catalog into a laboratory for the history of imagery. Two steps were needed to make this possible. First, methods had to be developed for easy data exchange between the online Iconclass system and other applications. This was done in several ways. Two versions of Iconclass Linked Open Data were developed, allowing other applications to make use of the data in both RDF-SKOS and JSON formats ${ }^{12}$. In addition, a feature was added to the Iconclass browser that enables users to create their own personal clipboards, where as many concepts may be stored as are needed for the description of a document. The clipboard's content can be exported in several default formats, to which other, user-defined formats can easily be added. 


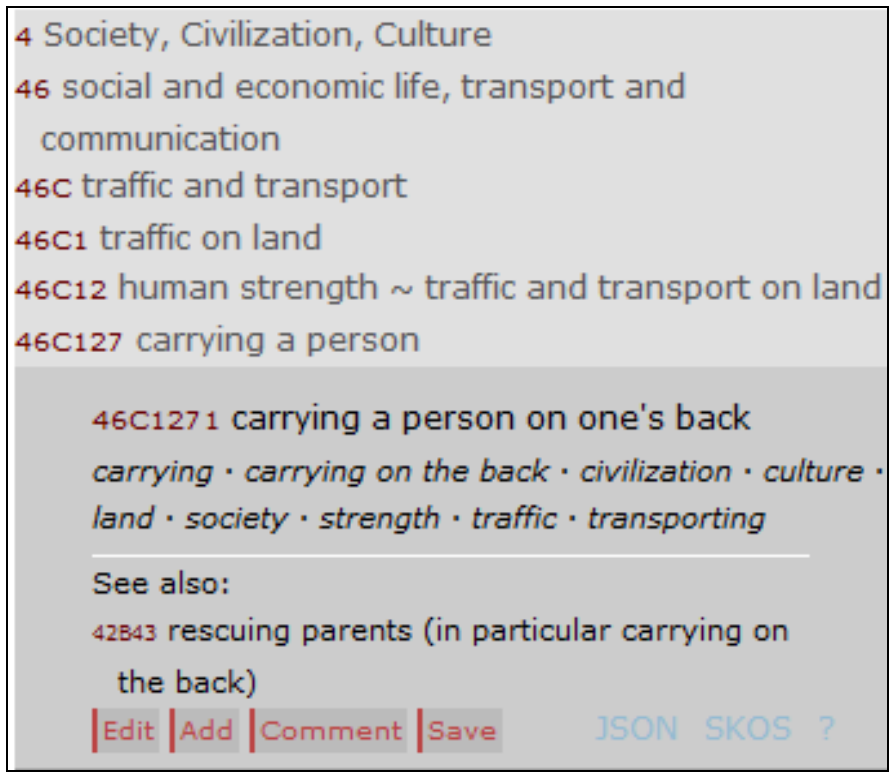

Figure 12. Screen shot taken from the online Iconclass system, showing the hierarchical chain of concepts that ends with the notation 46C1271 carrying a person on one's back.

Please note the commands in red at the bottom (Edit, Add, and Comment) are editorial tools. Users can comment on, correct, and even add new concepts to the vocabulary — in real time.

The Save command allows a user to append selected concepts to a personal clipboard, from which they can be easily imported into other Web applications, such as Arkyves.

\section{Iconclass \\ Outline . Clipboard \\ Clipboard for Hans Brandhorst with the unique ID: 53 E607 \\ X 54E11 Necessity of Mutual Co-operation \\ Clear Clipboard}

Figure 13. The author's personal Iconclass clipboard "loaded" with a concept that can be imported into other appliations.

Secondly, the aggregator Web resource, Arkyves, had to be opened up to allow its users to enrich existing catalog records from sources as widely dispersed as the Amsterdam Rijksmuseum and the Glasgow French emblem project. $^{13}$ 


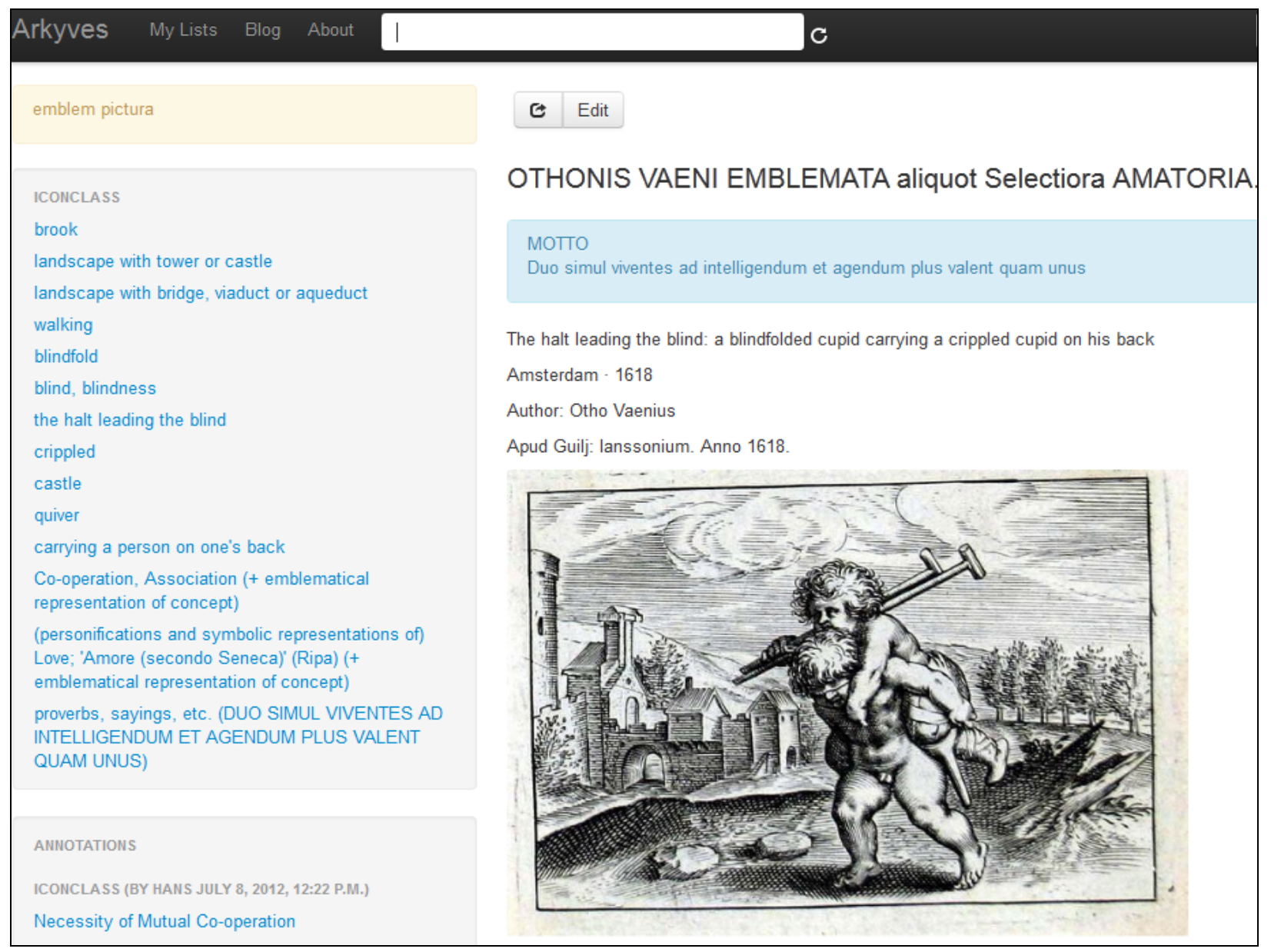

Figure 14. Screen shot from the Arkyves Web resource that showing the concept Necessity of Mutual Co-operation imported from the author's personal Iconclass clipboard.

Figure 14 shows the enrichment of a catalog record prepared by an institutional indexer. A term was imported from the same Iconclass vocabulary that was used for the original information. This new piece of information is formally kept apart, labelled as an ANNOTATION, indicating who the author of the annotation is. In this case the annotation is added to a record that was imported into Arkyves from the Utrecht Love Emblem project. $^{14}$ 


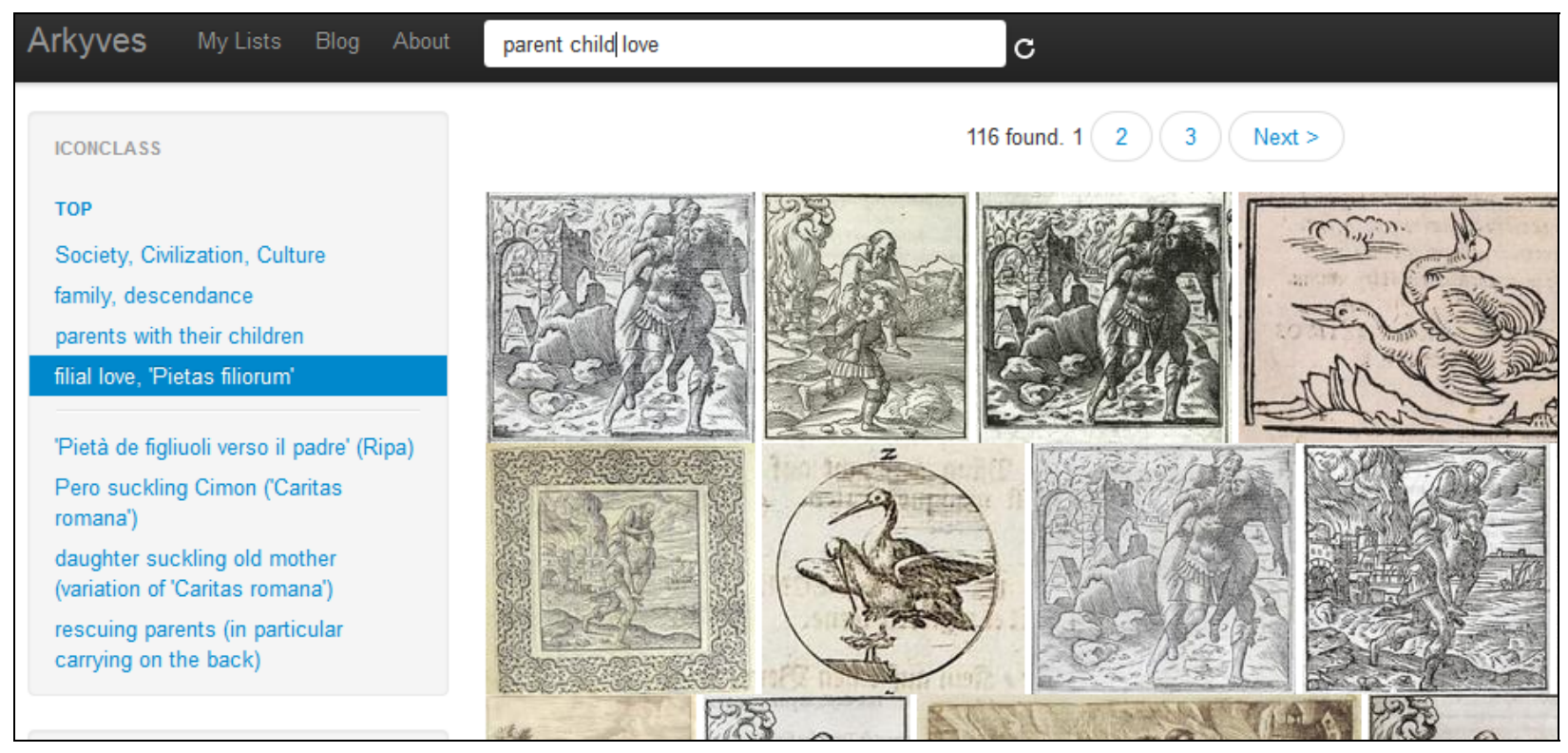

Figure 15. Search results in Arkyves for the query 42B4 filial love, "Pietas filiorum"

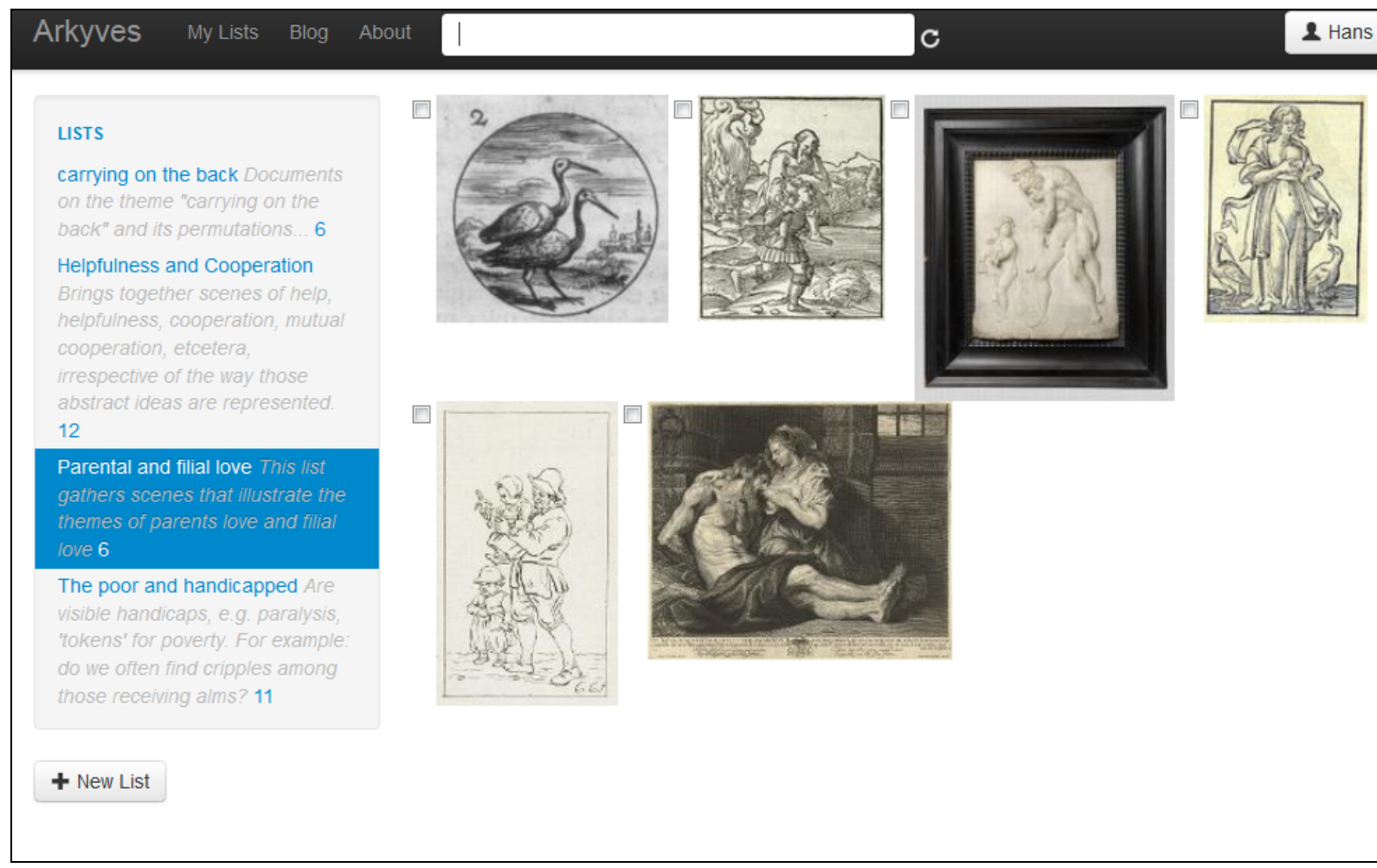

Figure 16. Creation of a list of documents for the theme "parental and filial love," for further research and enrichment.

Figures 15 and 16 summarily demonstrate how documents found among those gathered in Arkyves are stored in lists. These lists are created by the user, built from records found in Arkyves. Needless to say, it 
would be an important step forward to allow users to not just enrich information already in the database, but to add their own documents as well. The image shown in Figure 17 is an obvious candidate for inclusion.

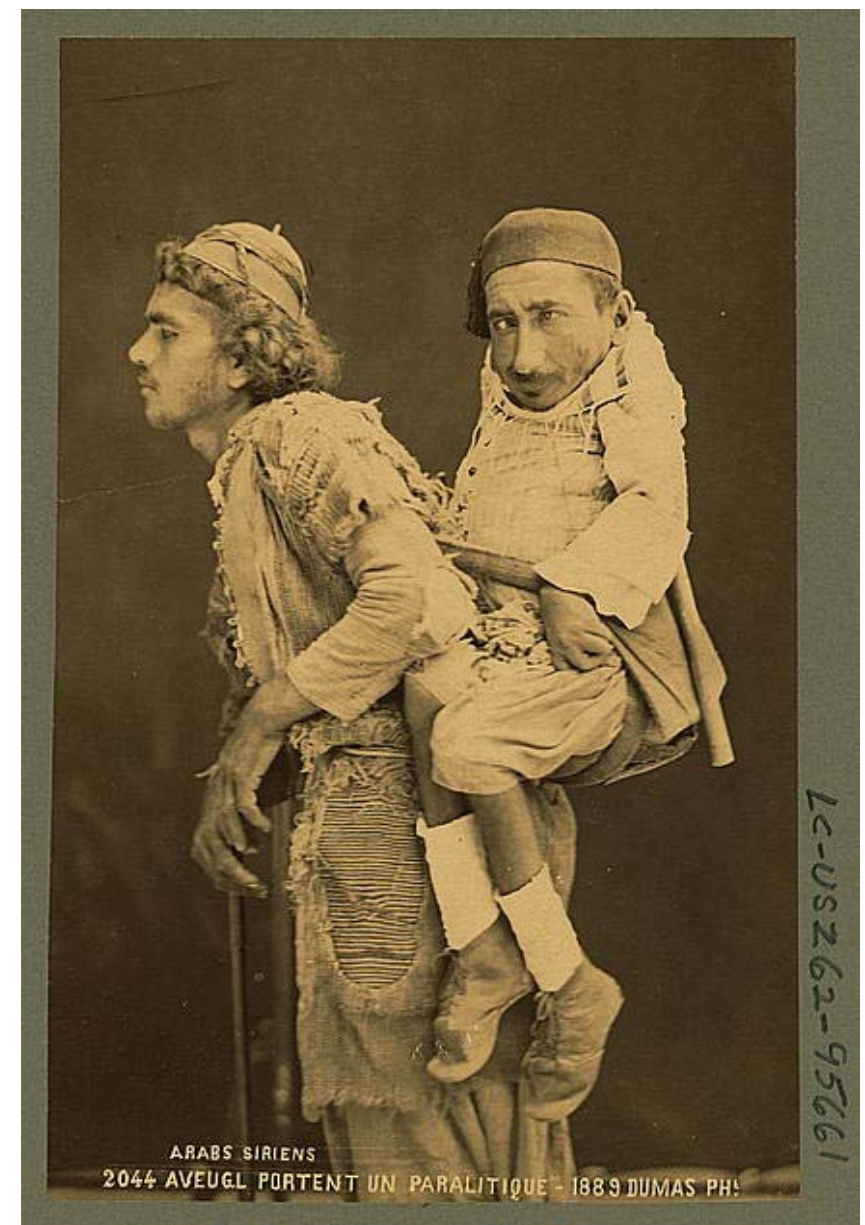

Figure 17. Library of Congress original: http://www.loc.gov/pictures/resource/cph.3b41806/ Wikipedia's iconographic metadata:

Deutsch: Ein blinder Mann trägt einen gelähmten Mann.

English: A blind man carrying a deformed man on his back in the Levant.

Français : Un homme aveugle porte un homme difforme sur son dos. Photo prise dans le Levant avant 1890.

Italiano: Un cieco trasporta un paralitico. Foto scattata in Siria nel 1889

Русский: Слепой человек переносит на спине калеку в Леванте

\section{Conclusion}

My concluding remarks must begin with a confession: I have manipulated my data, and I have done so for the purposes of this article. However, before my readers conclude that research originating from the Netherlands is now so tainted that researchers might as well confess to fraud in the actual article itself, ${ }^{15}$ I should point out that manipulation of data is what historians always do. In preparing this article, for example, I came across images that had been identified as showing the subject of the halt and the blind, but had not been described as an example of the Necessity of Mutual Co-operation. I added this indexing information myself, in this case in the Arkyves online resource, to make sure that I would be able to find these images again when I needed 
them. Thus I manipulated the original descriptive metadata - enriching it — in the course of creating my own little laboratory of images that I considered relevant to this article.

I should emphasize that this article is not specifically about the Arkyves online resource. I am convinced though, that many sites - such as ARTStor or BBC's Your Paintings, to name just two ${ }^{16}$ - will move in the same direction, inviting a broad range of both expert and non-expert users to enrich a common stock of material. I should also state that this article is, at least in part, about the Iconclass system. Sharing information will be much easier if a common, relatively languageindependent standard is used. That, however, is a subject for another article.

Whatever will cause optimism about the digitization of our visual heritage to grow, one aspect we cannot do without is the active participation of researchers, something that Johanna Drucker has convincingly argued. If we succeed in creating and refining the tools that will turn static catalogs into dynamic laboratories, the mood will change. My guess is that Aby Warburg would have had a field day.

\footnotetext{
${ }^{1}$ Although the words of this article are mine, its substance is the result of the close collaboration between an art historian (the author) and a technician, Web developer and programmer Etienne Posthumus. Neither the Arkyves nor the Iconclass website would exist without his work (see Note 10)

${ }^{2}$ Compare: P. van Huisstede, Der Mnemosyne-Atlas, Ein Laboratorium der Bildgeschichte. In: Aby M. Warburg,: "ekstatische Nymphe ... trauernder Flussgott"; Portrait eines Gelehrten, ed. by R. Galitz \& B. Reimers, Hamburg, 1995, 130-171.

${ }^{3}$ For information about PURLs, see http://en.wikipedia.org/wiki/Persistent_Uniform_Resource_Locator. The "Ur-PURL" is found at: http://purl.oclc.org.

${ }^{4}$ Compare: Aeneas carrying his father and Anchises carried by his son ...

${ }^{5}$ The combination of two emblems by Alciatus into a single picture by De Bry was also noted in the Web catalog of the Rijksmuseum. See: http://www.rijksmuseum.nl/collectie/zoeken/asset.jsp?id=RP-P-BI5232\&lang=nl (access July 1, 2012). The curious position of the lame man's deformed right leg in the 1551 edition of Alciatus suggests that De Bry copied this woodcut.

6 A beggar who suffers from the same handicap as the man who is carried by the blind man: he has lost the lower part of his right leg. His companion is sitting next to him on the ground.

The explanation in the center of the image reads:

Arida sylva viret densis vestita corymbis:

Fert claudum caecus: monstrat at ille viam.

Praebet largus opem poscenti dives egeno:

Tu nunquam miseros deservisse velis.

${ }^{7}$ By identifying the background scene as Aeneas carrying Anchises, C.-P. Warncke, (in Gabriel Rollenhagen, Sinn-Bilder. Ein Tugendspiegel (Harenberg, 1983)), demonstrates how closely related both themes are.

${ }^{8}$ Confusingly, there is a printing error at the end of the quote, reading Prov. 11:19 rather than Prov. 11:29.

${ }^{9}$ See for example: George Wither, A Collection of Emblemes (Printed by A.M. for Robert Allot, 1635), emblem 128.

${ }^{10}$ To be found at: http://www.arkyves.org and at: http://www.iconclass.org. Both sites are the product of work done by Etienne Posthumus (see Note 1) and the author.

${ }^{11}$ Not because finding them on the open Web means that I have implicit permission to print them in an article, but because, if necessary, I can refer the reader to all the images on the Web.
} 
12 Simple Knowledge Organization System (SKOS): a family of formal languages designed for representation of thesauri, classification schemes, taxonomies, subject-heading systems, or any other type of structured controlled vocabulary. See: http://en.wikipedia.org/wiki/Simple_Knowledge_Organization_System and: http://www.w3.org/2004/02/skos/intro. RDF (Resource Description Framework) and JSON (JavaScript Object Notation) are standard models for data interchange on the Web

See: http://www.w3.org/RDF/ and http://www.json.org/.

${ }^{13}$ See: http://new.arkyves.org/RIJKSMUSEUM/ and http://www.emblems.arts.gla.ac.uk/french/index.php (accessed July 8, 2012).

${ }^{14}$ See for the original, and much richer source of this record: http://emblems.let.uu.nl/va1618006.html

${ }^{15}$ Since 2011 we have had our share of scientific fraud in The Netherlands. For a retracted article by the once famous and now notorious social psychologist professor Huub Stapel, see:

http://www.sciencemag.org/content/332/6026/251.abstract.

${ }^{16}$ See: http://www.artstor.org and http://www.bbc.co.uk/arts/yourpaintings/. 